\title{
UNUSUAL LONGEVITY IN FALLOT'S TETRALOGY AND PSEUDOTRUNCUS ARTERIOSUS
}

\author{
BY \\ P. BOPP, J. RAST, AND P. W. DUCHOSAL \\ From the Centre de Cardiologie, University Hospital, Geneva, Switzerland \\ Received September 19, 1962
}

Recent advances in surgical techniques have made possible early and complete correction of Fallot's tetralogy. Therefore, opportunities to study the natural history of the disease in adult patients are now rare. This consideration prompted us to report the two following cases with catheterization and angiocardiographic data.

\section{CASE REPORTS}

Case 1. This woman was born on April 8, 1913. A cardiac murmur was discovered and cyanosis, squatting, and dyspnœa were noted at an early age. There was no history of rheumatic fever, diphtheria, or scarlet fever. A moderate degree of oligophrenia was noted. Three operations had been well tolerated: appendicectomy in 1932, hysterectomy in 1953, and cholecystectomy in 1954. Attacks of syncope had occurred recently. At the time of admission to the hospital (October 1961), the patient was 48 years old. She could not walk for more than one to two minutes, and she was practically bedridden. She had never held any job. Physical examination revealed: height $4 \mathrm{ft} .11 \mathrm{in} .(150 \mathrm{~cm}$.); weight, $117 \mathrm{lb} .(53 \cdot 2 \mathrm{~kg}$.); blood pressure $110 / 70 \mathrm{~mm}$. $\mathrm{Hg}$; pulse rate, regular, at $90 \mathrm{a}$ minute. The lips, tongue, and extremities were deeply cyanosed and moderate clubbing of the fingers and toes was observed. Hepatomegaly, neck vein distension, and peripheral œdema were absent.

Cardiac examination did not reveal any heave or thrill. The heart sounds were normal. A protomesosystolic murmur grade II/IV was audible at the apex and at the pulmonary area. No diastolic murmur was heard. Fluoroscopy was interrupted by a fainting spell. The cardiac size appeared to be increased (Fig. 1). The pulmonary vascularization seemed poor. The aorta was normal. The electrocardiogram (Fig. 2) showed a regular sinus rhythm, notchings of the QRS complex in the præcordial leads: increased $R$ waves in $V 1$ and $V 2$, and deep $S$ waves in V5 and V6 suggested right ventricular hypertrophy.

Hæmoglobin was 117 per cent; hæmatocrit 68 per cent; red blood cells $5 \cdot 5$ millions; urine examination,

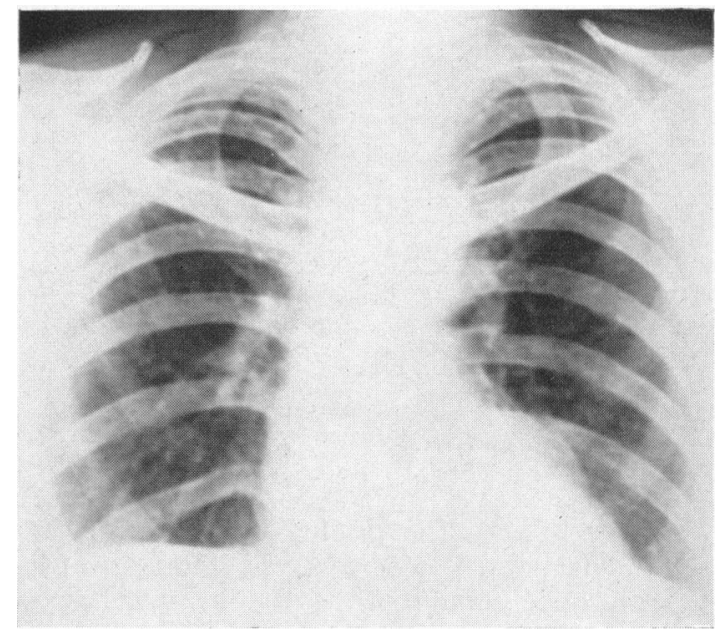

Fig. 1.-Case 1. Chest radiogram. normal. Details of cardiac catheterization and angiocardiography are given in the Table. From the right ventricle the catheter repeatedly entered the aorta but not the pulmonary trunk. The right ventricular systolic pressure was much increased. The severe arterial desaturation was explained by a right-to-left shunt at the ventricular level, demonstrated by the early opacification of an enlarged aorta (Fig. 3, 4). Angiocardiography showed pulmonary infundibular stenosis as well; no post-stenotic dilatation of the pulmonary 


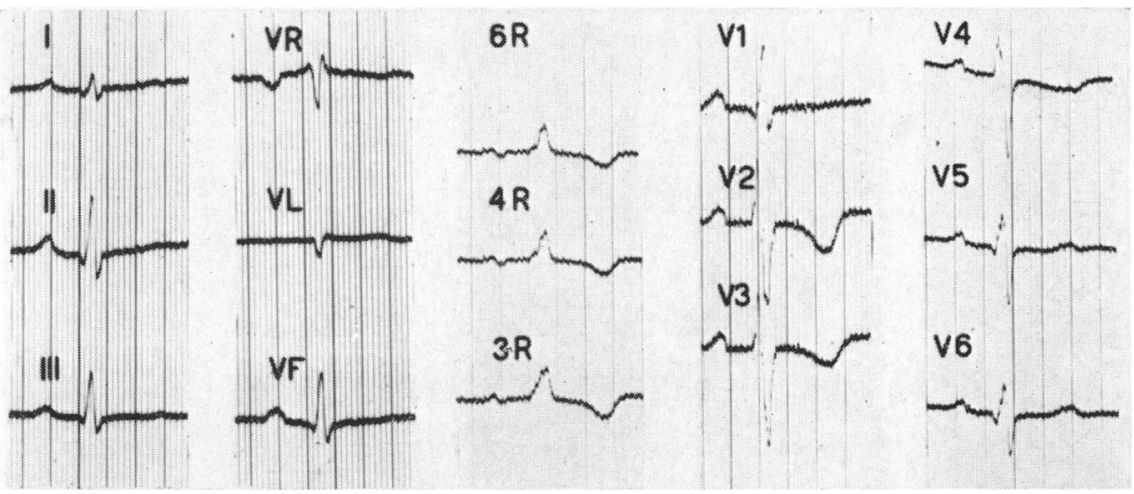

FIG. 2.-Case 1. Electrocardiogram, showing regular sinus rhythm, notchings of QRS complex, and increased $\mathbf{R}$ waves suggesting right ventricular hypertrophy.

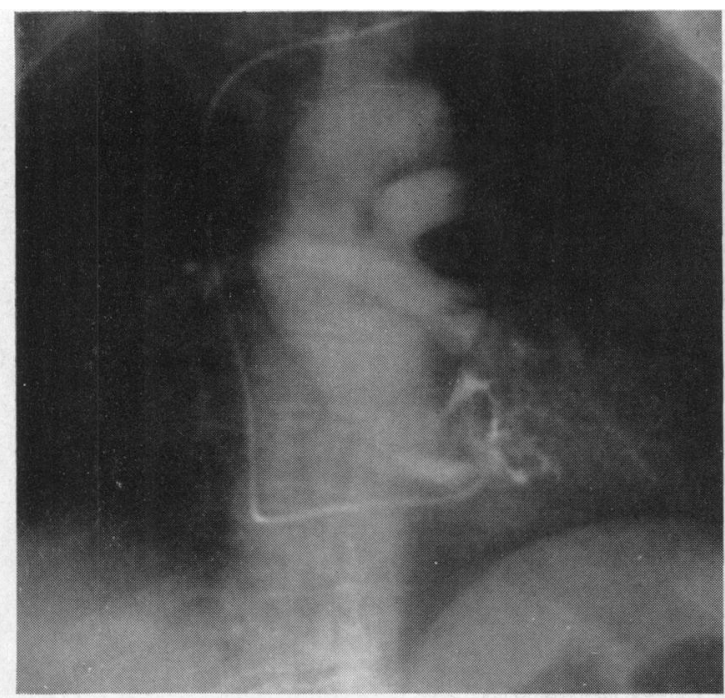

Fig. 3.-Case 1. Angiocardiogram, antero-posterior view, after $1 \frac{1}{2}$ seconds injection.

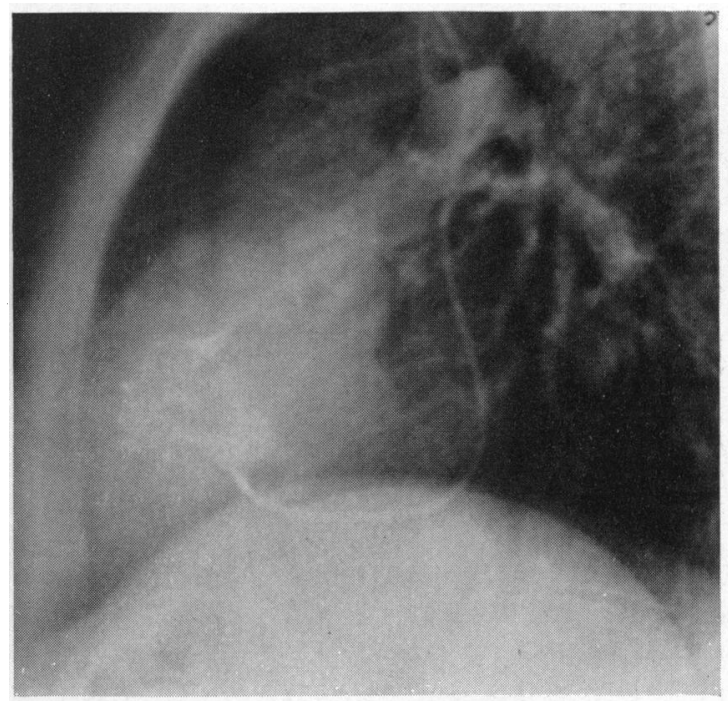

Fig. 4.-Case 1. Angiocardiogram, profile, after $1 \frac{1}{2}$ seconds injection.

artery was observed. Although it was not suggested clinically, an additional patent ductus arteriosus could not be ruled out. The diagnosis of tetralogy of Fallot was made; a palliative correction was considered, but was not done because of the fragility and the poor psychological background of the patient; she was discharged and a recent report from her physician indicates that her condition is unchanged. She is now 49 years old.

Case 2. This woman was born March 13, 1928. Cardiac auscultation was abnormal, and cyanosis and dyspnœa on exertion were noted at the age of 7 years. Squatting and bouts of syncope were absent. There was no history of rheumatic fever, diphtheria, scarlet fever, or tuberculosis, but since 1955 there were frequent episodes of bronchitis: her physical activity was restricted, but with careful management she was able to work as a part-time secretary, and even enjoyed yearly trips to the Island of Elba. In February 1961, a febrile episode necessitated her admission to the University Hospital. Blood cultures were positive for 
alpha-hæmolytic streptococci and bacterial endocarditis was diagnosed; after recovery, she was sent, several months later (November 1961), to the Centre de Cardiologie. At physical examination the patient was a 33-year-old woman; height, $5 \mathrm{ft} .3$ in. $(160 \mathrm{~cm}$.); weight, $133 \mathrm{lb}$. $(60.5 \mathrm{~kg}$.); blood pressure, 125/75 mm. $\mathrm{Hg}$; pulse rate regular, $92 / \mathrm{min}$. Cyanosis of the lips and extremities was noted as well as slight clubbing of the fingers. Neck vein distension and peripheral œdema were absent. Palpation disclosed a right ventricular heave but no thrill. The first heart sound was normal, but there was no second pulmonary sound. A continuous grade I/IV murmur was audible over the first and second left intercostal space. X-ray examination showed an increased heart size (Fig. 5) and both ventricles appeared to be enlarged. The pulmonary artery and the hila were diminished and the lungs were poorly vascularized. The aorta was dilated. The electrocardiogram (Fig. 6) was compatible with right ventricular hypertrophy. Hæmoglobin 103 per cent, hæmatocrit 59 per cent; urine examination, normal.

Details of cardiac catheterization are given in the Table. From the right ventricle, the catheter entered the aorta, then passed through a patent ductus into the pulmonary artery; the right ventricular systolic pressure was much increased. It was not possible to introduce the catheter directly from the right ventricle into the pulmonary trunk. There was a severe arterial desaturation.

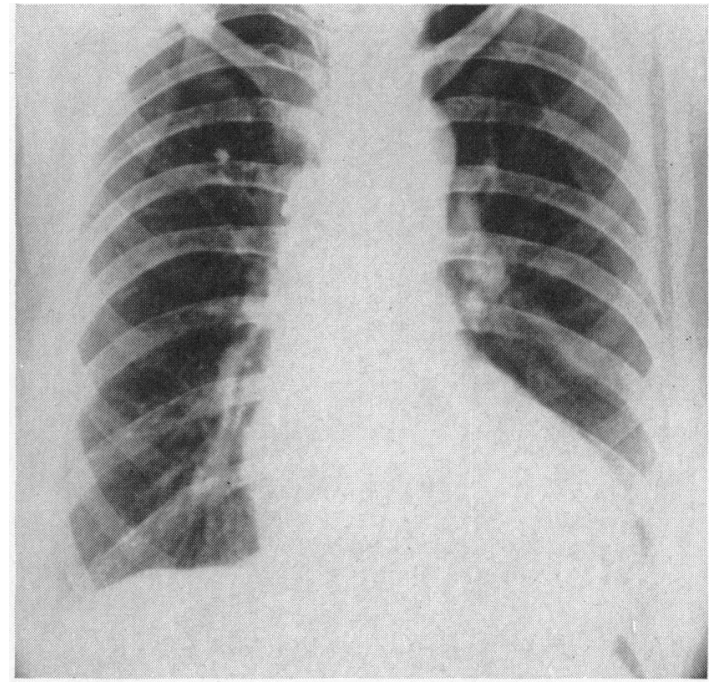

FIG. 5.-Case 2. Chest radiogram showing increased heart size.

Angiocardiography revealed pulmonary valve atresia (Fig. 7-10) and immediate filling of a considerably dilated aorta. The pulmonary arteries were faintly opacified by dye flowing through the patent ductus arteriosus. The diagnosis of Fallot's tetralogy with pulmonary valve atresia (pseudo-truncus arteriosus) was made. No surgical procedure was considered and the patient was discharged. Penicillin was prescribed on a prophylactic basis. Eight months later, a statement from her physician indicated that she was doing well, working half-time, and planning a trip abroad. She is now 34 years of age.

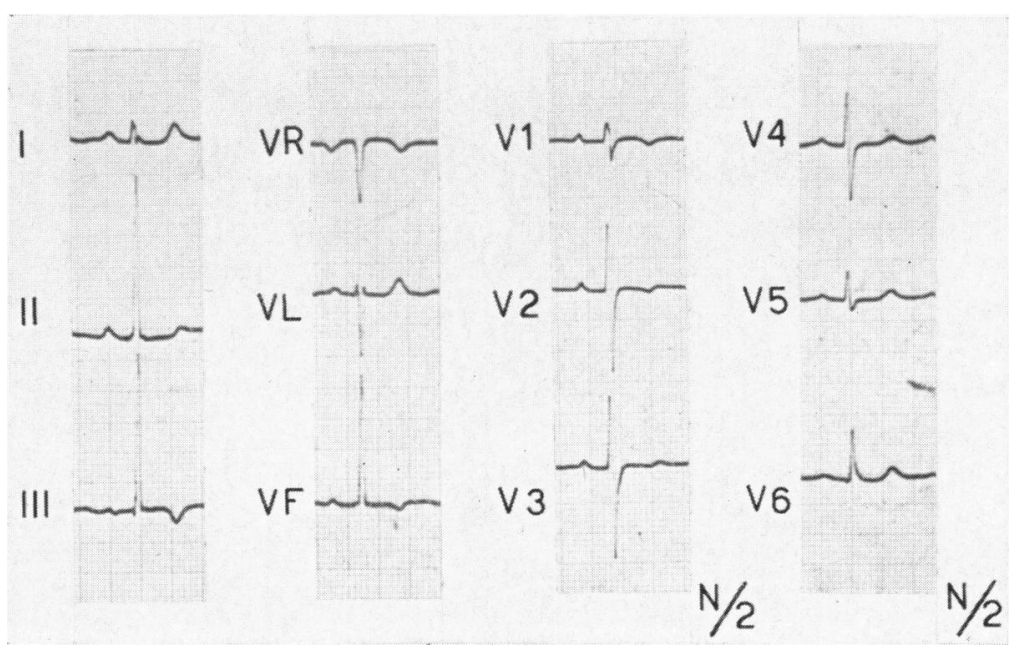

FIG. 6.-Case 2. Electrocardiogram indicates right ventricular hypertrophy. 


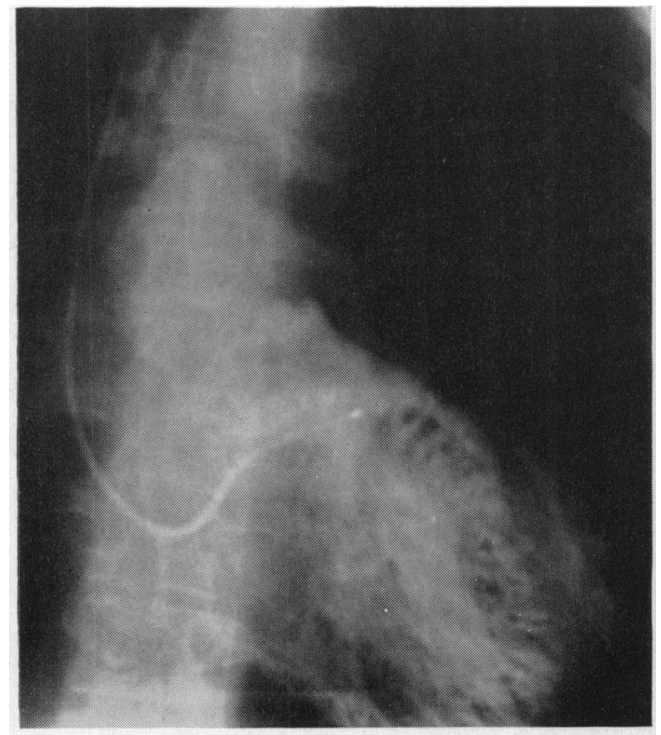

Fig. 7.-Case 2. Angiocardiogram, anteroposterior view, after $1 \frac{1}{2}$ seconds injection.

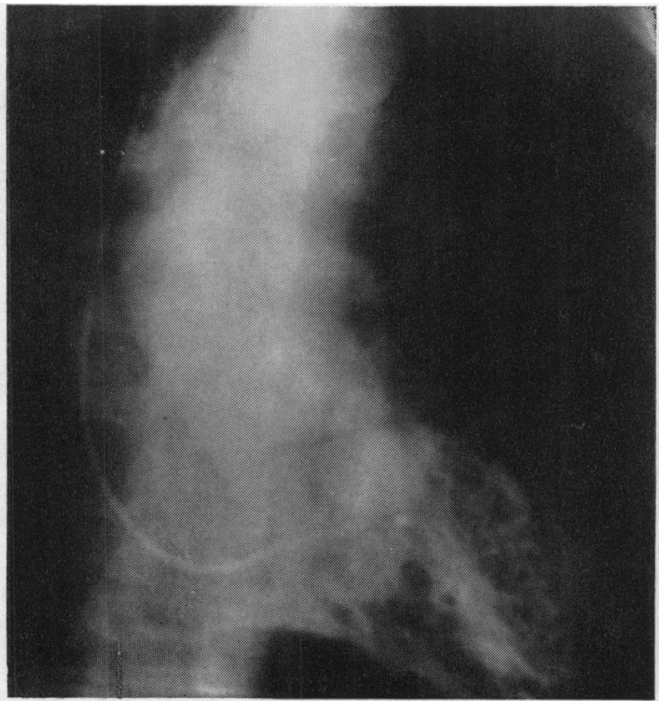

FIG. 9.-Case 2. Angiocardiogram, anteroposterior view, after 3 seconds injection.

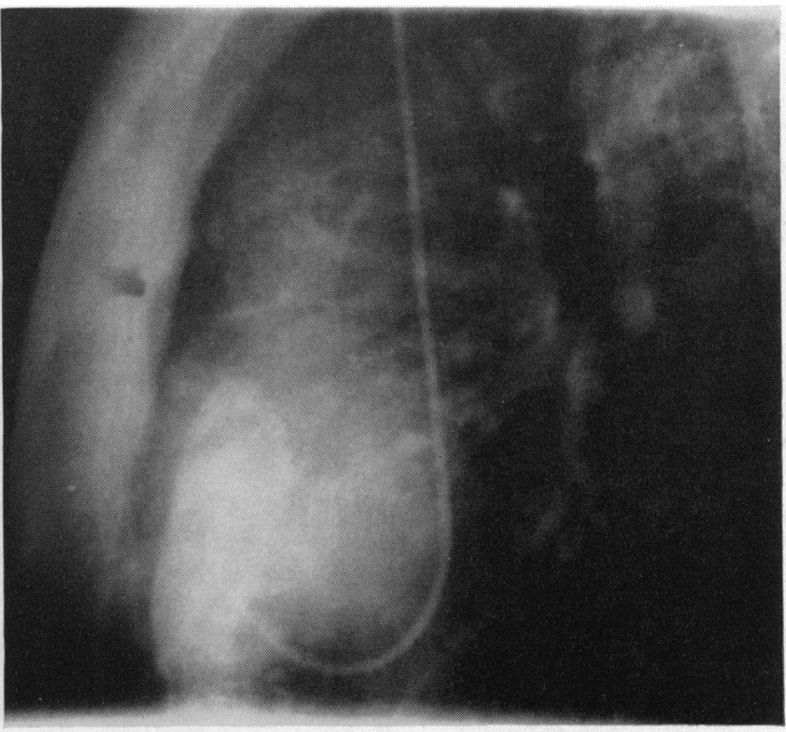

FIG. 8.-Case 2. Angiocardiogram, profile, after $1 \frac{1}{2}$ seconds injection.

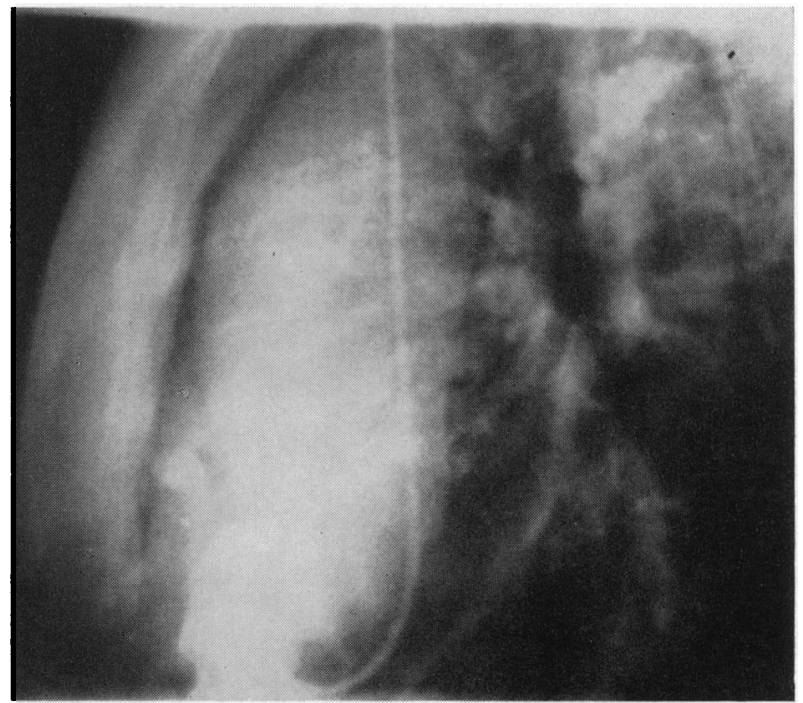

Fig. 10.-Case 2. Angiocardiogram, profile, after 3 seconds injection. 
TABLE

Catheterization Data

\begin{tabular}{|c|c|c|c|c|c|c|c|c|}
\hline & & & \multicolumn{3}{|c|}{ Case 1} & \multicolumn{3}{|c|}{ Case 2} \\
\hline & & & \multicolumn{2}{|c|}{ Oximetry } & \multirow{2}{*}{\begin{tabular}{|c|}
$\begin{array}{c}\text { Pressures } \\
(\mathrm{mm} . \mathrm{Hg})\end{array}$ \\
$\mathrm{S} / \mathrm{D}$ (mean)
\end{tabular}} & \multicolumn{2}{|c|}{ Oximetry } & \multirow{2}{*}{$\begin{array}{c}\begin{array}{c}\text { Pressures } \\
(\mathrm{mm} . \mathrm{Hg})\end{array} \\
\mathrm{S} / \mathrm{D} \text { (mean) }\end{array}$} \\
\hline & & & $\begin{array}{c}\text { Saturation } \\
\%\end{array}$ & $\begin{array}{c}\text { Volume } \\
\%\end{array}$ & & $\begin{array}{c}\text { Saturation } \\
\%\end{array}$ & $\underset{\%}{\text { Volume }}$ & \\
\hline $\begin{array}{l}\text { Superior vena cava } \\
\text { Inferior vena cava } \\
\text { Mean .. .. } \\
\text { Right atrium } \\
\text { Mean .. .. } \\
\text { Right ventricle }\end{array}$ & $\begin{array}{l}. \\
\cdots \\
. \\
.\end{array}$ & $\begin{array}{l}. \\
. \\
. \\
\cdots \\
. . \\
. \\
. .\end{array}$ & $\begin{array}{l}64 \\
66 \\
65 \\
63 \\
67 \\
65 \\
65 \\
67 \\
66 \\
68 \\
68 \\
- \\
- \\
67 \cdot 25 \\
- \\
95 \cdot 0 \\
72 \\
74 \\
73 \\
73 \\
- \\
-\end{array}$ & $\begin{array}{c}16 \cdot 70 \\
17 \cdot 25 \\
16 \cdot 97 \\
16 \cdot 45 \\
17 \cdot 50 \\
17 \cdot 00 \\
17 \cdot 00 \\
17 \cdot 50 \\
17 \cdot 25 \\
17 \cdot 75 \\
17 \cdot 75 \\
= \\
\overline{-} \\
17 \cdot 56 \\
\overline{-} \\
24 \cdot 8 \\
18 \cdot 80 \\
19 \cdot 30 \\
19 \cdot 05 \\
19 \cdot 05 \\
- \\
-\end{array}$ & $\begin{array}{c}\overline{-} \\
\overline{\overline{(3)}} \\
\overline{-} \\
\overline{-} \\
110 / \overline{7}(-) \\
\overline{-} \\
\bar{z} \\
\overline{-} \\
\overline{-} \\
\overline{-} \\
103 / 62(83) \\
\overline{-} \\
\overline{-}\end{array}$ & $\begin{array}{l}63 \\
61 \\
62 \\
64 \\
63 \\
61 \\
62 \cdot 7 \\
67 \\
67 \\
67 \\
76 \\
72 \\
66 \\
61 \\
68 \\
80 \cdot 5 \\
7 \bar{*} \cdot 5 \\
80 \cdot 5 \\
81 \cdot 0 \\
80 \cdot 75 \\
78 \cdot 0 \\
82 \cdot 0 \\
80\end{array}$ & $\begin{array}{l}13 \cdot 91 \\
13 \cdot 48 \\
13 \cdot 69 \\
14 \cdot 15 \\
13 \cdot 91 \\
13 \cdot 48 \\
13 \cdot 85 \\
14 \cdot 80 \\
14 \cdot 80 \\
14 \cdot 80 \\
16 \cdot 80 \\
15 \cdot 90 \\
14 \cdot 60 \\
13 \cdot 48 \\
15 \cdot 03 \\
17 \cdot 80 \\
21 \cdot 0 \\
17 \cdot 80 \\
17 \cdot 90 \\
17 \cdot 85 \\
17 \cdot 21 \\
18 \cdot 12 \\
17 \cdot 67\end{array}$ & $\begin{array}{c}\bar{z} \\
\overline{-} \\
\overline{-} \\
\overline{-} \\
\bar{z} \\
108 / 5(-) \\
\bar{z} \\
\bar{z} \\
\bar{z} \\
\overline{(12)} \\
\overline{-} \\
106 / 62(78) \\
\bar{z} \\
\overline{-}\end{array}$ \\
\hline $\begin{array}{l}\mathrm{O}_{2} \text { concentration } \\
\text { Systemic flow } \\
\text { Pulmonary flow } \\
\text { Right-to-left shunts }\end{array}$ & & & \multicolumn{3}{|c|}{$\begin{array}{c}250 \mathrm{ml} . / \mathrm{min} . \\
12.21 \mathrm{~min} . \\
3.451 . / \mathrm{min} . \\
8.751 . / \mathrm{min} .\end{array}$} & \multicolumn{3}{|c|}{$\begin{array}{c}298 \mathrm{ml} . / \mathrm{min} . \\
7.45 \mathrm{l} . / \mathrm{min} . \\
-\end{array}$} \\
\hline
\end{tabular}

* Estimated value.

\section{DisCussion}

Prolonged longevity in uncorrected tetralogy of Fallot is rare: the mean age of survival in Abbott's 85 cases (1936) was 12 years. However, a few patients reach a relatively advanced age. The 69year-old man reported by Bain (1954) is the oldest of all recorded cases. In 1929 White and Sprague published the case of an American composer who reached 59 years of age and was a musical celebrity. Other cases living beyond 50 years were observed by Strandell (1939), Feigin and Rosenthal (1943), Lian and Fleury (1949), Miller (1952), Marquis (1956), Bedford (1956), Campbell (1958), and Bowie (1961).

Such varying occupations as seamstress, automobile race driver, airplane pilot, coal-miner, labourer were listed in these patients. Cerebral complications were the most frequent causes of death. In these studies autopsy findings are presented but no angiocardiographic or hæmodynamic data are available, except in Ansell and Reiser's (1957) case.

The slight degree of dextroposition of the aorta and the relative mildness of the pulmonary stenosis may ensure a longer survival. The latter factor is also suggested by the even shorter life expectancy observed in pulmonary atresia: the oldest case described with this malformation was the dental mechanic described by East and Barnard (1938), who reached 33 years; another patient 
reported by these authors died at 20, whereas Bach's case (1928) succumbed at 30, and Wheeler and Abbott's (1928) at 29.

Thus our patient (Case 2) seems to have the most prolonged survival. However, there can be some doubt whether congenital or acquired pulmonary atresia was present. Indeed, Fontana and Edwards (1962) reported that out of five cases with pulmonary atresia, the only one who reached adult life had had bacterial endocarditis (the others died at 3, 11, 20 weeks, and 7 months respectively). In that case, autopsy revealed that the inflammatory process had caused atresia. Therefore, the longer survival of our second patient might be explained by the fact that atresia was produced at a later age by bacterial endocarditis on the basis of a pre-existent stenosis. However, in case of closure of a functional pulmonary opening, some deterioration of the clinical picture seems likely. This did not happen to our patient who still works part-time and travels abroad.

\section{SUMMARY}

Two cases of cyanotic congenital heart disease are reported because of their prolonged natural history. Both patients are still alive; the first one (a case of tetralogy of Fallot) is 49 years of age; the second one (a case of pseudo truncus arteriosus) is 34 years and is believed to be the oldest one ever described with this malformation. Hæmodynamic and angiocardiographic data are presented.

\section{REFERENCES}

Abbott, M. E. (1936). Atlas of Congenital Cardiac Disease. American Heart Association, New York.

Ansell, J. S., and Reiser, M. P. (1957). Prostatectomy in a patient with tetralogy of Fallot. Minn. Med., 40, 684.

Bach, F. (1928). A case of congenital morbus cordis studied over a period of twelve years. Lancet, $1,1009$.

Bain, G. O. (1954). Tetralogy of Fallot: survival to seventieth year. A.M.A. Arch. Path., 58, 176.

Bedford, D. E. (1956). Two cases of Fallot's tetralogy, shown at the section in 1929, exhibiting unusual longevity. Proc. roy. Soc. Med., 49, 314.

Bowie, E. A. (1961). Logevity in tetralogy and trilogy of Fallot. Discussion of cases in patients surviving 40 years and presentation of two further cases. Amer. Heart J., 62, 125.

Campbell, M. (1958). Late results of operations for Fallot's tetralogy. Brit. med. J., $2,1183$.

East, T., and Barnard, W. G. (1938). Pulmonary atresia and hypertrophy of the bronchial arteries. Lancet, $1,834$. Feigin, I., and Rosenthal, J. (1943). The tetralogy of Fallot. Amer. Heart J., $26,302$.

Fontana, R. S., and Edwards, J. E. (1962). Congenital Cardiac Disease, p. 80-81. Saunders, Philadelphia and London.

Lian, C., and Fleury, J. (1949). Survie jusqu'à 55 ans d'une maladie bleue (type Fallot). Arch. Mal. Caur, $42,1209$.

Marquis, R. M. (1956). Longevity and the early history of the tetralogy of Fallot. Brit. med.J., 1, 819.

Miller, S. I. (1952). Tetralogy of Fallot: report of a case that survived to his fifty-seventh year and died following surgical relief of gall-stone ileus. Ann. intern. Med., 36, 901.

Strandell, B. (1939). Fallot's tetrad-fall av sällsynt duration. Svenska Läk.-Tidn., $36,1513$.

Wheeler, D., and Abbott, M. E. (1928). Double aortic arch and pulmonary atresia, with pulmonic circulation maintained through a persistent left aortic root, in a man aged twenty-nine. Canad. med. Ass. J., 19, 297.

White, P. D., and Sprague, H. B. (1929). The tetralogy of Fallot. J. Amer. med. Ass., 92, 787. 